\title{
Toward Improved Use Of Value Creation Measures In Financial Decision-Making
}

\author{
John H. Hall, University of Pretoria, Republic of South Africa
}

\begin{abstract}
In the last two decades, numerous studies have been conducted to find sources and explanations for value creation and the value drivers of share returns or shareholder value creation by firms. This study aimed to determine whether more refined firm categorization and an increase in the number of variables analyzed would yield more robust information on value creation measures that financial decision-makers can use. Four different categories of firms were compiled. For each category, 11 different internal performance measures were regressed against two different external shareholder value creation measures. The empirical results show that different value creation measures explain shareholder value creation best for different categories of firms. Economic-based indicators provide higher information content than accounting-based indicators for financial decision-making. The information content of internal value drivers varied when different external shareholder value indicators were used. This study provides financial decisionmakers with a more specific indication of the use of shareholder value creation measures for specific firm types.
\end{abstract}

Keywords: Shareholder Value Creation; Economic Value Added; Market Value Added; Capital Intensive; Labor Intensive

\section{INTRODUCTION}

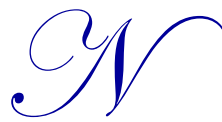

owadays, investors, shareholders, corporate managers and all other stakeholders in firms find themselves in what Mullaney (in Bloomberg.com, 2012) calls a "new upside-down world of investing... where bad news is good news for assets." This situation has arisen because of the worldwide recession, followed by the financial crises in 2008, and the more recent economic uncertainty in the Euro zone, the rising budget deficit (approaching the fiscal cliff) of the US, as well as the oil price uncertainty driven by the Arab Spring. One of the consequences of this financial climate is that investment returns have become more uncertain, volatile and lower (in relative terms) than they were a decade ago. It has therefore become all the more important to identify and refine ways to determine value in and improve returns from investments.

In the last two decades, authors such as Stewart (1991), Stern (1993), Biddle, Bowen and Wallace (1997), Chen and Dodd (1997, 2001), De Villiers and Auret (1998), Hall (1999), Ismail (2006), Lee and Kim (2009) and Kumar and Sharma (2011) have conducted research to identify the information content or best value drivers of share returns or shareholder value created by firms. These studies employed a number of internal performance measures. These measures can be divided into economic-based measures and traditional accounting-based measures. The economic-based measures include economic value added (EVA), refined economic value added (REVA), cash value added (CVA), return on capital employed (ROCE) and residual income (RI). The accounting-based measures include measures such as net operating profit after tax (NOPAT), cash flow from operations (OCF), earnings per share (EPS), return on assets (ROA) and return on equity (ROE). All these measures have been used to explain, express and measure shareholder value creation. Internal performance measures have been correlated with or regressed against external performance measures such as share price, market-adjusted share return (MAR) or market value added (MVA) to determine the internal measure that has the highest information content for or provides the best explanation for shareholder value creation. The results of these studies vary considerably. 
In most of these studies, the firm sample was compiled and treated as a homogeneous group - a crosssection of companies. However, it can be argued that no single shareholder value creation measure should be applied to all types of firms. Hence, this study focuses on whether different internal and external value indicators provide different (and better) information on the shareholder value created by different categories of firms.

In this study on South African data, four different categories of firms were analyzed. For each category, two dependent variables and 11 independent variables were used.

This study contributes new information which enables investors, shareholders and management to obtain a more specific indication of the shareholder value creation measures applied to a specific type of firm. This could lead to better investment decisions for increased returns. Moreover, using such information, better management decisions can be made to increase shareholder value. Finally, a better understanding of the financial environment within which a firm operates to create shareholder value is provided.

The rest of this paper is organized as follows: in the next section, a brief overview is given of the relevant literature, followed by a discussion of the research method. Thereafter, the empirical results are presented. Finally, in the conclusions to the study, a number of recommendations are made.

\section{LITERATURE REVIEW}

The economic turmoil in which the world has found itself since 2008 has caused a renewed focus on the goal of maximizing shareholder value. This focus is driven by shareholders, investment analysts and academic researchers. New and more refined ways of expressing shareholder value are continuously being developed and proposed. The principle of economic profit was expressed by Alfred Marshall in 1890, developed further by Fruhan (1979) and popularized by Stewart (1991) as EVA. Since then, EVA has given birth to shareholder value performance measures such as EVA momentum, discounted EVA, refined EVA (REVA) and cash value added (CVA).

Parallel to this evolution of shareholder value measurement models, research has been conducted in a quest for measures that explain the creation of shareholder value. Sharma and Kumar (2010) list and discuss 112 research papers published on EVA alone. Various other studies have been conducted on data from various countries to determine the information content of economic-based and accounting-based performance measures relating to shareholder value creation, which, in turn, is expressed by measures such as share prices, market-adjusted share returns and MVA. The results of these studies vary, and it seems that the unique features of every data set determine the results.

Table 1 summarizes the salient features of a selection of 18 studies covering the period from 1991 to 2011. (The variables mentioned in Table 1 are discussed later in this paper.)

Table 1 shows that 22 different independent variables have been used in the above studies, and that six different dependent variables have been used (after allowing for similarities between variables). Only two studies used more than one dependent variable.

The results of the studies listed in Table 1 indicate that the internal variables with the highest information content of shareholder value creation can be classified broadly into economic-based measures (EVA, REVA, discounted EVA and RI) and accounting-based measures (EBEI, OI, NI, EPS, NOPAT and OCF). In their attempt to find the value indicator with the highest information content on shareholder value created, of these 18 studies, ten found economic-based measures to be the best value indicators with the highest information content, seven found accounting-based measures to be the best, and one study found both an accounting- and an economic-based measure to be the best value indicators. 
Table 1: Results of studies on the information content of shareholder value performance measures, 1991-2011

\begin{tabular}{|c|c|c|c|c|}
\hline Authors & $\begin{array}{c}\text { Internal } \\
\text { independent } \\
\text { variable(s) }\end{array}$ & $\begin{array}{c}\text { External } \\
\text { dependent } \\
\text { variable(s) }\end{array}$ & Result & $\begin{array}{c}\text { Country; } \\
\text { statistical technique }\end{array}$ \\
\hline Stewart (1991) & EVA, EPS, ROE and others & MVA & EVA & $\begin{array}{l}\text { US; } \\
\text { LS regression }\end{array}$ \\
\hline Stern (1993) & $\begin{array}{l}\text { EVA, ROE, cash flow growth, } \\
\text { EPS growth, asset growth }\end{array}$ & MVA & EVA & $\begin{array}{l}\text { US; } \\
\text { LS regression }\end{array}$ \\
\hline $\begin{array}{l}\text { Milunovich and } \\
\text { Tsuei (1996) }\end{array}$ & EVA, EVA growth, ROE, FCF & MVA & EVA & $\begin{array}{l}\text { US; } \\
\text { LS regression }\end{array}$ \\
\hline O’Byrne (1996) & EVA, NOPAT, FCF & Market value $\div$ IC & EVA & US \\
\hline $\begin{array}{l}\text { Bacidore, Boquist, } \\
\text { Millbourn, and } \\
\text { Thakor (1997) }\end{array}$ & REVA, EVA & Stock returns & REVA & $\begin{array}{l}\text { US; } \\
\text { LS regression }\end{array}$ \\
\hline $\begin{array}{l}\text { Biddle, Bowen, } \\
\text { and Wallace (1997) }\end{array}$ & EVA, EBEI, RI, OCF & $\begin{array}{l}\text { Market-adjusted stock } \\
\text { returns }\end{array}$ & EBEI & $\begin{array}{l}\text { US; } \\
\text { LS regression }\end{array}$ \\
\hline $\begin{array}{l}\text { Chen and Dodd } \\
\text { (1997) }\end{array}$ & $\begin{array}{l}\text { EVA, change in EVA, ROC, } \\
\text { SPREAD, capital GROWTH, } \\
\text { EPS, ROA, ROE }\end{array}$ & Stock return & ROA, EVA & $\begin{array}{l}\text { US; } \\
\text { Regression }\end{array}$ \\
\hline $\begin{array}{l}\text { Bao and Bao } \\
(1998)\end{array}$ & NI, EVA, Value added & $\begin{array}{l}\text { Equity value; share } \\
\text { price }\end{array}$ & $\begin{array}{l}\text { Value added } \\
\text { (accounting) }\end{array}$ & $\begin{array}{l}\text { US; } \\
\text { LS regression }\end{array}$ \\
\hline $\begin{array}{l}\text { De Villiers and } \\
\text { Auret (1998) }\end{array}$ & EPS, EVA per share & Share price & EPS & $\begin{array}{l}\text { South Africa; } \\
\text { Regression }\end{array}$ \\
\hline Hall (1999) & $\begin{array}{l}\text { EVA, discounted EVA, ROA, } \\
\text { ROE, ROCE, EPS, DPS, and } \\
\text { others }\end{array}$ & MVA & $\begin{array}{l}\text { EVA (same result } \\
\text { as discounted EVA) }\end{array}$ & $\begin{array}{l}\text { South Africa; } \\
\text { LS regression }\end{array}$ \\
\hline $\begin{array}{l}\text { Worthington and } \\
\text { West (2004) }\end{array}$ & EVA, RI, NCF, EBEI & Stock returns & EVA & $\begin{array}{l}\text { Australia; } \\
\text { Regression }\end{array}$ \\
\hline De Wet (2005) & $\mathrm{EVA}, \mathrm{CFO} \div \mathrm{IC}, \mathrm{ROA}$ & MVA & $\mathrm{CFO} \div \mathrm{IC}$ & $\begin{array}{l}\text { South Africa; } \\
\text { LS regression }\end{array}$ \\
\hline Ismail (2006) & EVA, RI, NI, NOPAT, OCF & Stock returns & NI, NOPAT & $\begin{array}{l}\text { UK; } \\
\text { Panel data regression }\end{array}$ \\
\hline $\begin{array}{l}\text { Kyriazis and } \\
\text { Anastassis (2007) }\end{array}$ & EVA, NI, OI & Stock returns; MVA & NI, OI & $\begin{array}{l}\text { Greece; } \\
\text { Regression }\end{array}$ \\
\hline Erasmus (2008) & CVA, EVA, RI, EBEI, CFO & $\begin{array}{l}\text { Market adjusted } \\
\text { returns }\end{array}$ & RI & $\begin{array}{l}\text { South Africa; } \\
\text { LS regression }\end{array}$ \\
\hline Chmelikova (2008) & EVA, ROA, ROE & $\begin{array}{l}\text { Market value of } \\
\text { equity } \div \text { equity }\end{array}$ & EVA & $\begin{array}{l}\text { Czech republic; } \\
\text { Regression }\end{array}$ \\
\hline $\begin{array}{l}\text { Lee and Kim } \\
(2009)\end{array}$ & $\begin{array}{l}\text { EVA, REVA, MVA, CFO, } \\
\text { ROA, ROE }\end{array}$ & $\begin{array}{l}\text { Market adjusted } \\
\text { returns }\end{array}$ & REVA, MVA & $\begin{array}{l}\text { US; } \\
\text { Pooled regression }\end{array}$ \\
\hline $\begin{array}{l}\text { Kumar and Sharma } \\
\text { (2011) }\end{array}$ & $\begin{array}{l}\text { EVA, NOPAT, OCF, ROE, } \\
\text { ROCE }\end{array}$ & MVA & NOPAT, OCF & $\begin{array}{l}\text { India; } \\
\text { LS regression }\end{array}$ \\
\hline
\end{tabular}

Abbreviations: LS (least squares), FCF (free cash flow), EBEI (earnings before extraordinary items), spread (ROCE minus weighted average cost of capital, WACC), NI (net income attributable to ordinary shareholders), value added (an accounting profit measure), DPS (dividend per share), IC (invested capital).

Source: Own observation and compilation.

The inconsistency of the results of these studies leads investors, shareholders and researchers to ask the following questions: Based on the results of these studies, what is actually the performance measure with the best information content on shareholder value created? Which measure must be used? Is there a clear "winner"? Is there another way to determine the best value indicator? Can any additional research provide more insight into the information content of a firm's internal performance measures? This study aimed to address these issues.

\section{Independent and dependent variables}

The identification and selection of independent and dependent variables used in this study were based on the results of the 18 prior studies presented in Table 1. The following independent variables (after eliminating duplication) were chosen: 
- $\quad$ EVA - EVA, developed by the Stern Stewart consulting firm, is calculated as follows (Stewart, 1991):

$$
\text { EVA }=\left(\frac{\text { NOPAT }}{\text { Capital }}-\text { WACC }\right) \times \text { Capital, }
$$

where

capital is Stern Stewart's capital employed at the beginning of the year,

NOPAT is the net operating profit with all required adjustments as proposed by Stern Stewart, and

WACC is calculated by weighing the cost of equity (calculated using the capital asset pricing model) and the cost of debt.

- $\quad$ EVAgrowth - the change or growth in EVA is the simple annual growth rate in EVA between two years.

- $\quad$ REVA - REVA was developed by Bacidore, Boquist, Millbourn, and Thakor (1997), and is calculated as follows:

$$
\text { REVA }=\left(\frac{\text { NOPAT }}{\text { marketcapital }}-\text { WACC }\right) \times \text { market capital, }
$$

where market capital is the market value of equity at the beginning of the year, plus the book value of total interest-bearing debt. The key difference between EVA and REVA is that, in the case of REVA, the capital charge for the period is based on the market value of the firm, instead of the economic book value of capital, as in the EVA calculation.

- $\quad$ EBEI - net income before extraordinary items and tax $=\mathrm{OCF}+$ accruals. Accruals consist of total operating accruals such as depreciation, amortization, $\Delta$ non-cash current assets and $\Delta$ current liabilities, other than interest-bearing current liabilities (Biddle, Bowen, and Wallace, 1997).

- $\quad$ NOPAT - net operating profit after tax is EBEI + an after-tax interest adjustment.

- $\quad \mathrm{NI}$ - net income attributable to shareholders.

- $\quad$ ROA - the return on average total assets (inflation adjusted).

- $\quad$ EPS - the headline earnings per share.

In addition to the above variables, ROE, ROCE and the spread (ROCE minus WACC) are added as independent variables in this study:

- $\quad \mathrm{ROE}-$ the return on average equity (inflation adjusted).

- $\quad$ ROCE - ROCE $=\frac{\text { NOPAT }}{\text { capital }}$; NOPAT and capital have already been defined above.

- $\quad$ The SPREAD - this is calculated as ROCE minus WACC, and is an indicator of excess return achieved above the total cost of capital.

The independent variables thus consisted of five economic-based variables (EVA, EVA growth, REVA, ROCE and the SPREAD). The remaining six independent variables were accounting-based measures. It was expected that choosing these "winning variables" from the 18 studies listed above as the independent variables of this study would allow a winner to be computed in this study, based on the winners in previous studies.

The dependent variables used in this study were, as is the case with the independent variables, taken from the 18 studies presented in Table 1 . These variables were the following:

- $\quad$ MVA - the calculation of MVA is based on the difference between the total market value of debt and equity (MV) and total capital (TC) provided by lenders and shareholders for management (Stewart, 1991). However, the approach used in this study is to express the MVA performance indicator as a ratio (MV $\div$ TC), which effectively standardises all the enterprises in the category to the same size and further facilitates comparisons between large and small firms. 
- $\quad$ Market-adjusted share return (MAR) - calculated as a firm's 12-month compounded share return, less the 12-month return on the all share index (ALSI) of the Johannesburg Stock Exchange (JSE). These returns were calculated for a period ending three months after the firm's financial year-end to ensure the inclusion of financial statement information in the share price.

The objective of this research was firstly to determine the best external shareholder value creation measure for a specific category of firms. A second objective was to determine whether economic- or accounting-based value indicators provide the highest information content on (have the biggest impact on) shareholder value creation. A third objective was to determine the best internal predictor of value for a specific category of firms. It can be argued that different categories of firms have different value drivers. More specifically, the following hypotheses were tested:

$\mathbf{H}_{1}$ Whether MVA or MAR is the best shareholder value creation measurement differs between various categories of firms.

$\mathbf{H}_{2}$ Irrespective of a specific category of firms, the impact of economic-based value indicators on shareholder value creation is higher than that of accounting-based measures.

$\mathbf{H}_{3}$ What the internal value indicators (drivers) with the highest impact on shareholder value creation are differs between different categories of firms.

$\mathbf{H}_{4}$ The internal value indicators (drivers) with the highest impact on shareholder value creation differ, depending on whether MVA or MAR is used as the external shareholder value creation measure.

These hypotheses were tested using the methodology described in the next section.

\section{RESEARCH METHODOLOGY}

The research methodology followed in this study is set out below. The sampling process, the independent and dependent variables, as well as the statistical techniques that were applied, are discussed. The data used in this research were supplied by the McGregor BFA, a large supplier of quality financial data in South Africa.

\section{Categories}

Firms listed on the Johannesburg Stock Exchange (JSE) for the period from 2001 to 2011 were used. The following sectors were excluded from the sample: banks, basic resources (mining companies), financial services, insurance, investment and real estate. These sectors were excluded because the nature of their activities and their fundamentals differ substantially from those of the sectors that were included in the study. A total of 206 firms were included.

One would expect there to be a difference between the value indicators of firms that create shareholder value on the one hand, and those of firms that destroy shareholder value on the other. For the purposes of this study, and to compile a category of positive shareholder value creation firms, EVA was used to determine the shareholder value creation of a firm. Hence, the firms were ranked according to their total EVA over the period for which data were available for them. All 121 firms with a total positive EVA formed part of this category. The remaining 85 firms were categorized as destroying value.

The value drivers of capital intensive firms could differ from those of labor intensive firms. A third and fourth category were therefore created, based on the capital intensity or labor intensity of firms. A distinction was made between capital intensive (CI) and labor intensive (LI) firms, based on a firm's mix of capital and labor. A firm was classified as a CI firm if the firm was more automated, with less focus on a labor intensive production process. Firms were considered to be LI if they used more labor intensive processes and focused less on automated production processes. It was expected that CI firms would have different value indicators from LI firms. For the purposes of this study, CI and LI firms were distinguished on the basis of their ratio of net fixed assets (NFA) to total assets (TA), in line with the approach adopted by Bloom, Lambrechts and Le Roux (2002). (In order to determine the capital and labor intensity of a firm, it would have been useful if the ratio of the number of employees to total assets could be calculated. However, very few firms make public their number of employees. Therefore, for the purposes of this study, this method of determining capital or labor intensity could not be used.) In this context, a firm was considered CI if its NFA is a large percentage of its TA, and an LI firm had a low ratio of NFA:TA. The 
NFA:TA ratios of the companies in the sample of this study were calculated. By considering the $25 \%$ of firms that had respectively the highest and lowest NFA:TA ratios, the list of CI and LI firms to be used in this study was compiled. The $49 \mathrm{CI}$ firms chosen operate primarily in the chemicals and construction sectors. The category of 49 LI firms chosen comes mainly from the retail and technology sectors.

\section{Independent and dependent variables}

The independent variables identified in the literature study were EVA, EVA growth, REVA, EBEI, NOPAT, RI, NI, ROA, EPS, ROE, ROCE and the SPREAD. The dependent variables were MVA and MAR. These variables were calculated for the 206 firms over the 11-year period under review. Outliers that fell outside three standard deviations from the mean were discarded. Missing values were populated using the previous year's figure. (For the purposes of this study, this method of populating missing values was tested and was found to have no impact on the statistical validity of the results.)

\section{The model specification}

Almost all the prior studies cited above used ordinary leased squared (OLS) analysis for a set of crosssectional time series data. By applying panel data analysis, observations can be conducted on multiple phenomena over various periods for the same firm (Baltagi, 2008). This results in more reliable regression techniques for the cross-sectional time series data, and greatly enhances the validity of regression results. For the current study, the data set was an unbalanced panel.

The multiple regression model used to test the information content of the independent variables on the dependent variables, based on panel data regression analysis, was the following:

$\mathrm{MVA}_{i t s}=\beta_{0}+\beta_{1} \mathrm{EVA}_{i t s}+\beta_{2} \mathrm{EVAgrowth}_{i t s}+\beta_{3} \mathrm{REVA}_{i t s}+\beta_{4} \mathrm{EBEI}_{i t s}+\beta_{5} \mathrm{NOPAT}_{i t s}+\beta_{6} \mathrm{NI}_{\text {its }}$ $+\beta_{7} R O A_{i t s}+\beta_{8} \mathrm{EPS}_{i t s}+\beta_{9} \mathrm{ROE}_{i t s}+\beta_{10} R O C E_{i t s}+\beta_{11} \operatorname{spread}_{i t s}+\varepsilon_{i t s}$.

The main difference between this equation and a standard OLS regression is that the intercept term is allowed to vary non-stochastically over $i$ or $t$. It is known as the "fixed effects model".

In Equation 1 above, $\mathrm{MVA}_{i t s}$ is the market value added for Firm $i$ in Period $t$ for Category $s . \mathrm{EVA}_{i t s}$ is the amount of economic value added for Firm $i$ in Period $t$ for Category $s$. EVAgrowth ${ }_{i t s}$ is the growth in EVA for Firm $i$ in Period $t$ for Category $s$. REVA $i t s$ is the amount of refined economic value added for Firm $i$ in Period $t$ for Category $s$, and so on. $\varepsilon_{i t s}$ is a stochastic error term for Firm $i$ at Time $t$ for Category $s ; i=1$ to 206; $t=1$ (2001) to 11 (2011), and $s=1$ to 4 for the four different categories of firms.

Market adjusted return $i t s=\beta_{0}+\beta_{1} \mathrm{EVA}_{i t s}+\beta_{2} \mathrm{EVAgrowth}_{i t s}+\beta_{3} \mathrm{REVA}_{i t s}+\beta_{4} \mathrm{EBEI}_{\text {its }}+\beta_{5} \mathrm{NOPAT}_{i t s}$ $+\beta_{6} \mathrm{NI}_{i t s}+\beta_{7} R O A_{i t s}+\beta_{8} \mathrm{EPS}_{i t s}+\beta_{9} \mathrm{ROE}_{i t s}+\beta_{10} R O C E_{i t s}+\beta_{11} \operatorname{spread}_{i t s}+\varepsilon_{i t s}$.

where

the market-adjusted return its $_{\text {s }}$ is the market adjusted return for Firm $i$ in Period $t$ for Category $s$, EVA $_{i t s}$ is the amount of economic value added for Firm $i$ in Period $t$ for Category $s$, and so on.

\section{Tests for data validity}

In order to model the data, certain data validity tests must be conducted. This ensures that the structure of the data lends itself to modelling, and that the data conform to the model's assumptions. The structure of the data and the models were therefore analyzed by considering serial correlation, stationarity, heteroskedasticity and endogeneity. Data validity tests were performed on all four categories. 
Serial correlation (SC) refers to a situation where a variable is correlated to one or more of its own lags, or the lags of other variables in the model. The Durbin-Watson test was used to identify SC, which can be either positive or negative. For panel data, the methodology and critical values given by Bhargava, Franzini and Narendranathan (1982) were used. There were 11 time periods (T) in the category, which prompted the use of Table II in the paper by Bhargava, Franzini and Narendranathan (1982). The following additional criteria were used: the number of cross-sections $(\mathrm{H})$ was approximated to 250 for Category 1, to 150 for Category 2, and to 50 for Categories 3 and 4. The number of independent regressors was set at 11. The critical values for Categories 1 to 4 are set out in Table 2 (see the next section), along with the conclusions drawn regarding each model. To correct for serial correlation, the Prais-Winston transformation was used, where the error term is corrected using a relevant transformation. The transformed model was then run and tested for serial correlation. This process was followed iteratively, until serial correlation was no longer present.

Stationarity of the data was also considered. Various unit root tests were performed on the data - all variables were found to be stationary.

Heteroskedasticity was also considered. The structure of the data did not allow the test for heteroskedasticity to be conducted. Therefore, potential heteroskedasticity was corrected for by using White's cross-section coefficient variance method. In this analysis, an adjustment was made for heteroskedasticity, regardless of whether it can be tested for or not.

Finally, endogeneity - or misspecification - refers to a correlation between the error term and one or more of the independent variables. This was tested for, and adjusted where necessary.

In the next section, the results from the empirical analysis are presented and discussed.

\section{RESULTS OF THE EMPIRICAL ANALYSIS}

The results of the empirical analysis are presented by discussing descriptive statistics, followed by the regression results.

\section{Descriptive statistics}

The descriptive statistics for the total sample of 206 firms for the 11-year period are presented in Table 2 below.

Table 2: Descriptive statistics

\begin{tabular}{lccccc}
\hline \multicolumn{1}{c}{ Variable } & Mean & Median & Maximum & Minimum & Std. deviation \\
\hline MVA & 4.41 & 1.58 & 678.64 & -84.86 & 36.05 \\
MAR (\%) & 9.86 & -3.53 & $2,330.79$ & -136.09 & 114.56 \\
EVA (Rm) & 163.32 & 12.06 & $37,986.38$ & $-142,148.35$ & $4,090.55$ \\
EVAgrowth (\%) & -3.11 & -0.14 & 76.99 & $-1,910.07$ & 57.14 \\
REVA (Rm) & $-2,464.00$ & -1.12 & $31,379.34$ & $-357,515.29$ & $22,655.67$ \\
EPS (cent) & 663.58 & 63.90 & $825,937.69$ & -505.00 & $19,580.81$ \\
EBEI (Rm) & $1,498.11$ & 130.10 & $376,776.87$ & -851.10 & $10,214.19$ \\
NOPAT (Rm) & 648.70 & 89.14 & $42,583.41$ & $-130,437.54$ & $4,046.14$ \\
ROA (\%) & 14.40 & 14.24 & 208.28 & -267.35 & 20.88 \\
NI (Rm) & 901.32 & 74.36 & $267,447.52$ & $-1,769.30$ & $7,028.45$ \\
ROE (\%) & 46.16 & 18.01 & $40,651.26$ & $-4,290.92$ & $1,052.96$ \\
ROCE (\%) & 12.33 & 17.45 & $1,171.53$ & $-5,178.40$ & 188.21 \\
SPREAD $(\%)$ & 3.11 & 3.22 & 516.56 & -576.04 & 31.09 \\
\hline
\end{tabular}

The dependent variables in this study were MVA and MAR. Table 2 shows that the mean of the MVA created by the sample was more than four times their capital employed. The MAR has a mean of nearly $10 \%$, which means that the companies' share prices outperformed the market. 
In respect of the independent variables, the mean EVA was positive at R163m, but the growth in EVA had a negative mean of $3.11 \%$. This might be an indication of the economic crises in the world economy since 2008 . The REVA displayed a large negative mean, an indication that this is a more rigorous economic value indicator (using market capital in contrast to economic capital used by EVA). The remaining independent variables displayed positive figures. Notably, the positive mean SPREAD of $3.1 \%$ was also an indication of the value creation potential of the companies under review.

\section{Regression results}

Before any model is evaluated using panel data techniques, a test for poolability should be done. Poolability essentially determines whether data should be combined into a single pool (analysed using a traditional linear model), or should be analysed as a panel, where cross-sectional and time-effects are also considered. The test compares a restricted model (a behavioural equation with the same parameters over time and firms) with an unrestricted model (the same behavioural equation with different parameters over time and firms) - in essence, an Ftest (Baltagi, 2008). The critical F-value is given for each model in its respective results table. In each case, the null hypothesis $\left(\mathrm{H}_{0}\right)$ is that the cross-section and time-series parameters are all equal to zero. If the null hypothesis is not rejected, the firms do not have any characteristic inherent in their structure that would account for differences in their performance, and the periods do not account for any of the variations between the different firms. If this is the case, a panel data approach is not relevant. The results are set out below.

\begin{tabular}{|c|c|c|c|c|c|c|c|c|}
\hline \multirow{2}{*}{$\begin{array}{c}\text { Dependent } \\
\text { variable }\end{array}$} & \multirow{2}{*}{ Estimation } & & \multirow{2}{*}{ Category } & \multirow{2}{*}{\multicolumn{2}{|c|}{ Adj. R2 }} & \multicolumn{2}{|c|}{ F-value } & \multirow{2}{*}{ p-value } \\
\hline & & & & & & F-value & $\boldsymbol{F}_{\text {Crit }}$ & \\
\hline MVA & Pooled model & & 1 & & & 6.206 & 1.178 & 0.000 \\
\hline MVA & Fixed effects model & & 1 & & & - & - & 0.000 \\
\hline MAR & Pooled model & & 1 & & & 1.308 & 1.178 & 0.268 \\
\hline MAR & Fixed effects model & & 1 & & & - & - & 0.003 \\
\hline \multirow{2}{*}{$\begin{array}{c}\text { Dependent } \\
\text { variable }\end{array}$} & \multirow{2}{*}{ Estimation } & \multirow{2}{*}{ Category } & \multicolumn{5}{|c|}{ Durbin-Watson (DW) } & Endogeneity \\
\hline & & & $L D W$ & $D W$ & $U D W$ & Serial & relation & Hausman Test \\
\hline MVA & Pooled model & 1 & - & - & - & & & - \\
\hline MVA & Fixed effects model & 1 & 1.9255 & 1.198 & 1.9445 & Pos & $\mathrm{SC}$ & Endogeneity present \\
\hline MAR & Pooled model & 1 & - & - & - & & & - \\
\hline MAR & Fixed effects model & 1 & 1.9255 & 1.846 & 1.9445 & Pos & $\mathrm{SC}$ & No endogeneity present \\
\hline
\end{tabular}

From the analysis of Category 1, it can be seen that the F-values for poolability for both the MVA and MAR model were greater than the critical value. Therefore, both models would benefit from using panel data techniques. The p-value in the above table stated the overall fit of the models. Fixed effect models of both MAR and MVA were significant at a 5\% level. The adjusted $\mathrm{R}^{2}$ for the model using MVA as the dependent variable showed a goodness of fit of $71.1 \%$. However, the goodness of fit on the MAR model was very low, with an adjusted $\mathrm{R}^{2}$ of only 0.028. Both models displayed positive serial correlation. The MVA model was also endogenous. Overall, MAR was therefore the preferred dependent variable for Category 1.

\begin{tabular}{|c|c|c|c|c|c|c|c|c|}
\hline \multirow{2}{*}{$\begin{array}{c}\text { Dependent } \\
\text { variable }\end{array}$} & \multirow{2}{*}{ Estimation } & & \multirow{2}{*}{ Category } & \multirow{2}{*}{ Adj. R2 } & \multicolumn{3}{|c|}{ F-value } & \multirow{2}{*}{ p-value } \\
\hline & & & & & \multicolumn{2}{|c|}{ F-value } & $\boldsymbol{F}_{\text {Crit }}$ & \\
\hline MVA & Pooled model & & 2 & 0.393 & \multicolumn{2}{|c|}{2.798} & 1.221 & 0.000 \\
\hline MVA & Fixed effects model & & 2 & 0.478 & \multicolumn{2}{|c|}{-} & - & 0.000 \\
\hline MAR & Pooled model & & 2 & -0.003 & \multicolumn{2}{|c|}{1.24} & 1.221 & 0.860 \\
\hline MAR & Fixed effects model & & 2 & 0.018 & & - & - & 0.070 \\
\hline \multirow{2}{*}{$\begin{array}{c}\text { Dependent } \\
\text { variable }\end{array}$} & \multirow{2}{*}{ Estimation } & \multirow{2}{*}{ Category } & \multicolumn{5}{|c|}{ Durbin-Watson (DW) } & Endogeneity \\
\hline & & & $L D W$ & $D W$ & $U D W$ & Seri & orrelation & Hausman Test \\
\hline MVA & Pooled model & 2 & - & - & - & & - & - \\
\hline MVA & Fixed effects model & 2 & 1.9003 & 1.4 & 1.9318 & & ive SC & Endogeneity present \\
\hline MAR & Pooled model & 2 & - & - & - & & - & - \\
\hline MAR & Fixed effects model & 2 & 1.9003 & 1.68 & 1.9318 & & ive SC & Endogeneity present \\
\hline
\end{tabular}


The poolability test for both MVA and MAR suggested that panel data techniques should be used for both dependent variables. A fixed effect model for MVA was significant at a 5\% level of significance, with an adjusted $\mathrm{R}^{2}$ of 0.478 . MAR, on the other hand, was only significant at a $10 \%$ level of significance, with an $\mathrm{R}^{2}$ of 0.018 . Both fixed effect models also exhibited positive serial correlation and were endogenous. One could overlook the adjusted $\mathrm{R}^{2}$ values for both the fixed effect models in deciding on their relevance, and on whether they make theoretical sense and are significant overall. However, endogeneity may not be overlooked, as it suggests that the functional form of a model does not represent the data accurately. Therefore, in considering Category 2, neither MVA nor MAR is recommended as the dependant variable. It is possible that with different structural forms, these dependent variables may reflect the data more accurately, but testing other functional forms fell beyond the scope of the current study.

\begin{tabular}{|c|c|c|c|c|c|c|}
\hline \multirow{2}{*}{$\begin{array}{c}\text { Dependent } \\
\text { variable }\end{array}$} & \multirow{2}{*}{ Estimation } & \multirow{2}{*}{ Category } & \multirow{2}{*}{ Adj. R2 } & \multicolumn{2}{|c|}{ F-value } & \multirow{2}{*}{ p-value } \\
\hline & & & & F-value & $\boldsymbol{F}_{\text {Crit }}$ & \\
\hline MVA & Pooled model & 3 & 0.092 & 12.873 & 1.385 & 0.000 \\
\hline MVA & Fixed effects model & 3 & 0.564 & - & - & 0.000 \\
\hline MAR & Pooled model & 3 & 0.003 & 1.544 & 1.385 & 0.318 \\
\hline MAR & Fixed effects model & 3 & 0.050 & - & - & 0.015 \\
\hline
\end{tabular}

\begin{tabular}{|c|c|c|c|c|c|c|c|}
\hline \multirow{2}{*}{$\begin{array}{l}\text { Dependent } \\
\text { variable }\end{array}$} & \multirow{2}{*}{ Estimation } & \multirow{2}{*}{ Category } & \multicolumn{4}{|c|}{ Durbin-Watson (DW) } & \multirow{2}{*}{$\begin{array}{c}\text { Endogeneity } \\
\text { Hausman Test }\end{array}$} \\
\hline & & & $L D W$ & $D W$ & $U D W$ & Serial Correlation & \\
\hline MVA & Pooled model & 3 & - & - & - & - & - \\
\hline MVA & Fixed effects model & 3 & 1.8072 & 0.429 & 1.9029 & Positive SC & No endogeneity present \\
\hline MAR & Pooled model & 3 & - & - & - & - & - \\
\hline MAR & Fixed effects model & 3 & 1.8072 & 1.909 & 1.9029 & No SC & No endogeneity present \\
\hline
\end{tabular}

The F-test for poolability recommended the use of a fixed effects model for both MVA and MAR. Both fixed effect models were found to be significant at a 5\% level. MVA had a higher adjusted $\mathrm{R}^{2}$ than MAR, with values of 0.564 and 0.050 respectively. Neither model was endogenous, but MVA did exhibit positive serial correlation. Overall, for capital intensive firms, MAR was selected as the most appropriate dependent variable and model.

\begin{tabular}{|c|c|c|c|c|c|c|c|c|}
\hline \multirow{2}{*}{$\begin{array}{l}\text { Dependent } \\
\text { variable }\end{array}$} & \multirow{2}{*}{ Estimation } & & \multirow{2}{*}{ Category } & \multirow{2}{*}{\multicolumn{2}{|c|}{ Adj. R2 }} & \multicolumn{2}{|c|}{ F-value } & \multirow{2}{*}{ p-value } \\
\hline & & & & & & F-value & $\boldsymbol{F}_{\text {Crit }}$ & \\
\hline MVA & Pooled model & & 4 & & & 6.328 & 1.385 & 0.000 \\
\hline MVA & Fixed effects model & & 4 & & & - & - & 0.000 \\
\hline MAR & Pooled model & & 4 & & & 1.165 & 1.385 & 0.782 \\
\hline MAR & Fixed effects model & & 4 & & & - & - & 0.341 \\
\hline \multirow{2}{*}{$\begin{array}{c}\text { Dependent } \\
\text { variable }\end{array}$} & \multirow{2}{*}{ Estimation } & \multirow{2}{*}{ Category } & \multicolumn{5}{|c|}{ Durbin-Watson (DW) } & Endogeneity \\
\hline & & & $L D W$ & $D W$ & $U D W$ & Serial C & ation & Hausman Test \\
\hline MVA & Pooled model & 4 & - & - & - & & & - \\
\hline MVA & Fixed effects model & 4 & 1.8072 & 1.201 & 1.9029 & Posi & & Endogeneity present \\
\hline MAR & Pooled model & 4 & - & - & - & & & - \\
\hline MAR & Fixed effects model & 4 & 1.8072 & 2.086 & 1.9029 & & & No endogeneity present \\
\hline
\end{tabular}

A test for poolability showed that MVA was a candidate for panel data techniques, but that a fixed effects model should not be considered for MAR. It was therefore not surprising that a fixed effects model for MAR did not perform well. Furthermore, a simple linear (pooled) model of MAR was found not to be significant. Therefore it seems that MAR did not fit the data well when labour-intensive firms were examined. A fixed effects model of MVA was highly significant, and boasted a high goodness of fit, and the model also displayed positive serial correlation and endogeneity. This suggested that, overall, neither MVA nor MAR should be considered to analyze labour intensive firms.

In summary, the results of these analyses indicated that different shareholder value creation measures (dependent variables) should be considered to evaluate a specific firm category. The MAR was found to be a better shareholder value creation measure than MVA in the case of the total category and for capital intensive firms. For 
some categories of firms (Category 2 - firms with a positive EVA, and Category 4 - labour intensive firms), neither MVA nor MAR should be used as a shareholder value creation measure. Therefore, for the purposes of this study, no further tests were conducted on these categories of firms. Therefore, if a firm can be assigned to a specific category, a particular shareholder value creation measure could provide a better indication of the shareholder value creation potential of that firm than another measure. This finding supports Hypothesis 1, that different shareholder value creation measures provide the best shareholder value creation measurements for different firm categories.

From this initial exploratory analysis, three models were selected as preferred models for further evaluation. Both the MVA and the MAR fixed models were considered for Category 1 (the total sample), and MAR was considered for the third category (capital intensive firms). The results are presented in Table 3.

Table 3: Regression results.

\begin{tabular}{|c|c|c|c|}
\hline \multirow[b]{2}{*}{$\begin{array}{c}\text { Independent } \\
\text { variable }\end{array}$} & \multicolumn{3}{|c|}{ Regression coefficients } \\
\hline & $\begin{array}{c}\text { Category 1: } \\
\text { All firms } \\
\text { MAR }\end{array}$ & $\begin{array}{c}\text { Category 1: } \\
\text { All firms } \\
\text { MVA }\end{array}$ & $\begin{array}{c}\text { Category 3: } \\
\text { Capital intensive } \\
\text { MAR }\end{array}$ \\
\hline EVA & 0.000005 & 0.000001 & 0.000000 \\
\hline EVAgrowth & 0.078932 & 0.001883 & -0.874027 \\
\hline REVA & 0.000000 & 0.000000 & 0.000002 \\
\hline EPS & 0.000483 & 0.000089 & 0.013420 \\
\hline EBEI & 0.000001 & -0.000000 & 0.000000 \\
\hline NOPAT & -0.000003 & -0.000000 & -0.000005 \\
\hline ROA & 0.106576 & -0.503470 & 0.705641 \\
\hline NI & -0.000002 & 0.000000 & 0.000003 \\
\hline ROE & 0.001151 & -0.001166 & -0.000352 \\
\hline ROCE & -0.007451 & -0.085468 & -0.052423 \\
\hline SPREAD & 0.213846 & 0.143678 & 0.262302 \\
\hline Adjusted $\mathrm{R}^{2}$ & 0.028 & 0.711 & 0.050 \\
\hline p-value & 0.003 & 0.000 & 0.015 \\
\hline Durbin-Watson & 1.846 & 1.198 & 1.909 \\
\hline
\end{tabular}

A number of the regression coefficients of the MAR model estimated for Category 1 (all firms) had a negligible effect (very close to zero) on the dependent variable. The variable SPREAD was found to have the greatest effect on the dependent variable. For every unit increase in SPREAD, a corresponding increase of 0.21 units was observed in MAR. The variables ROA and EVAgrowth also had a noticeable positive effect on MAR. Moreover, MVA could be modelled using Category 1 data. Again, a number of the independent regressors were found to have very little effect on MVA. Once again, the greatest positive effect was achieved by increasing the variable SPREAD. An increase in the SPREAD resulted in a 0.14 unit increase in MVA. In terms of its magnitude, ROA had the greatest effect, albeit a negative effect. For every unit increase in ROA, MVA declined by 0.50 units. Lastly, a fixed effects model using MAR and data from capital intensive firms was also considered. The variable with the highest information content was the ROA - a one unit change in ROA had a profound effect on MAR, increasing the dependent variable by 0.71 units. The biggest negative regression coefficient was produced by the variable EVAgrowth, which decreased the MAR by 0.87 units for every one unit increase in the variable.

The results of this analysis can now be used to address Hypotheses 2, 3 and 4 for this study. In the first place, Hypothesis 2, namely that economic-based indicators should have a higher impact on a shareholder value creation than accounting-based indicators, was accepted, because the economic-based measure SPREAD produced consistently higher regression coefficients in all categories of firms. Secondly, Hypothesis 3 states that the value indicators with the highest value impact will differ between the various categories of firms. This hypothesis had to be rejected, as the SPREAD (an economic-based indicator) and EPS (an accounting-based indicator) were found to be consistently high impact value drivers in all three categories of firms. There was thus no consistency in respect of economic-based or accounting-based value indicators' providing the highest information content regarding shareholder value creation. Lastly, Hypothesis 4 states that the value indicators with the highest value impact differ, depending on the external shareholder value creation measure used. This was accepted, as the ROA produced positive values for dependent variable MAR, but a negative impact for dependent variable MVA. In addition, the 
SPREAD had a markedly higher value for the firm categories with MAR as the dependent variable, but a lower coefficient (impact) when MVA was used as the shareholder value creation measure.

This study set out to determine whether a more refined categorization of firms and the use of more variables would yield more robust information for financial decision-makers. This goal was achieved, as the results indicate that different shareholder value measurements do explain shareholder value creation best for different categories of firms. In addition, it was established that the information content of the value drivers differed as, and when, different shareholder value creation measures were being used. The implications of these findings for investors, shareholders, and management are addressed in the conclusion to this study.

\section{CONCLUSION}

Past studies on the information content of shareholder value creation measures produced varied and contradictory results. A possible reason for this was that the samples of firms used were treated as a homogenous group, and that there was little variation in the shareholder value creation measure used. The aim of the current study was to investigate whether different value creation measures best explain shareholder value created for different categories of firms. Moreover, is the information content of economic-based measures better than that of accounting-based measures? Do these internal value indicators differ, depending on the external shareholder value creation measure applied?

Four hypotheses were tested in terms of the results of the empirical analysis. It was found that different categories of firms do indeed have different value creation measures that best explain shareholder value creation. In the case of the total category and the category for capital intensive firms, MAR was found to be a better indicator of shareholder value than MVA. For firms with a positive EVA and labor intensive firms, neither of these two measures should be used. The economic-based value indicators performed better than the accounting-based measures, with the SPREAD (ROCE minus WACC) turning out to be the best. The ROA and EPS were also found to be good internal value indicators. The results also showed that the internal value indicators differed when different external shareholder value measures (MVA or MAR) were used.

The goal and nature of this study made it difficult to compare the results of this study with the results of other studies, notably those mentioned in Table 1 . The very essence of this study was that it attempted an analysis that had not been widely done before. If one looks at the results of the studies in Table 1, it is clear that the current results support those in the study by De Villiers and Auret (1998) on South African data, which found EPS to be the best value indicator - the current study also found that the EPS has a high information content in explaining shareholder value. One of the results of this research, namely that the SPREAD is the value indicator with the highest information content on shareholder value creation, is different from the results of the studies listed in Table 1.

This study makes a number of contributions to the existing body of knowledge. Firstly, it suggests that no single shareholder value measure should be used on a specific type of firm - different firms seem to require different shareholder value measures. It is a matter of "horses for courses": financial decision-makers need to find the shareholder value measurement that best suits a particular type of firm. A second contribution is the finding that when different external shareholder value creation measurements are used, the information content of the internal value indicators also changes. This information is valuable to the management of firms that want to concentrate their efforts on a specific value driver to increase shareholder value creation. Lastly, the findings of this study should make investors, shareholders, and management aware of the multiplicity and complexity of the financial analysis of shareholder value creation.

The relatively small data basis may be regarded as a possible limitation of this study, but the data base reflects the size of the South African economy. The results of this analysis indicate that the search for the best, consistent internal value indicator to be used for a specific firm is far from over. Therefore, the search for a better way to analyze shareholder value creation must continue. It is recommended that more dependent variables be employed as external shareholder value measures. In addition, more firm categories and different firm categories, such as different industries, should be investigated in similar analyses. Intensifying and refining the independent 
and dependent variables, as well as adding more and different categories of firms, improves the chances of finding the holy grail of the information content of shareholder value creation measures.

\section{AUTHOR INFORMATION}

Prof. John H. Hall is a member of the Department of Financial Management at the University of Pretoria in the Republic of South Africa. He has published numerous articles in scholarly journals (some of which have received best paper awards) and has presented research papers at a number of conferences both locally and internationally. He has supervised a number of doctoral and Master's students. He can be contacted at john.hall@up.ac.za

\section{REFERENCES}

1. Bacidore, J. M., Boquist, J. A., Millbourn, T. T., \& Thakor, A. V. (1997). The search for the best financial performance measure. Financial Analysts Journal, 53(3) May/June, 11-20.

2. Baltagi, B. H. (2008). Econometric analysis of panel data. New York, NY: Wiley.

3. Bao, B., \& Bao, D. (1998). Usefulness of value added and abnormal economic earnings: An empirical examination. Journal of Business Finance \& Accounting, 25(1) \& (2), 251-264.

4. Biddle, G. C., Bowen, R. M., \& Wallace, J. S. (1997). Does EVA ${ }^{\circledR}$ beat earnings? Evidence on associations with stock returns and firm values. Journal of Accounting and Economics, 24(3), 301-336.

5. Bhargava, A., Franzini, L., \& Narendranathan, W. (1982). Serial correlation and the Fixed Effects Model. Review of Economic Studies, 49(4), 533-549.

6. Bloom, J. Z., Lambrechts, I. J., \& Le Roux, N. J. (2002). The behaviour of financial ratios for capital and labour intensive enterprises during the economic cycle. Journal for Studies in Economics and Econometrics, 26(1), 51-70.

7. Bloomberg.com. (2012). U.S. stocks rise amid stimulus bets after employment data. Retrieved from http://www.bloomberg.com/news/print/2012-09-07/u-s-stock-advance-before-payrolls-jobless-data.html.

8. Chen, S., \& Dodd, J. L. (1997). Economic Value Added $\left(\mathrm{EVA}^{\mathrm{TM}}\right)$ : An empirical examination of a new corporate performance measure. Journal of Managerial Issues, 9(3), 318-333.

9. Chen, S., \& Dodd, J.L. (2001). Operating income, residual income and EVA ${ }^{\mathrm{TM}}$ : Which metric is more value relevant? Journal of Managerial Issues, 13(1), 65-86.

10. Chmelikova, G. (2008). Economic Value Added versus traditional performance metrics in the Czech foodprocessing sector. International Food and Agribusiness Management Review, 11(4), 49-65.

11. De Villiers, J. U., \& Auret, C. J. (1998). A comparison of EPS and EVA as explanatory variables for share price. Journal for studies in Economics and Econometrics, 22(2), 47-63.

12. De Wet, J. H. v. H. (2005). EVA versus traditional accounting measures of performance as drivers of shareholder value - A comparative analysis. Meditari Accountancy Research, 13(2), 1-16.

13. Erasmus, P. (2008). The relative and incremental information content of the value-based financial performance measure Cash Valued Added (CVA). Management Dynamics, 17(1), 2-15.

14. Hall, J. H. (1999). Correlating internal and external performance yardsticks in the evaluation of corporate wealth creation. Meditari Accountancy Research, 7, 123-143.

15. Fruhan, W. E. (1979). Financial strategy: Studies in the creation, transfer, and destruction of shareholder value. Homewood, IL: Irwin.

16. Ismail, A. (2006). Is Economic Value Added more associated with stock return than accounting earnings? The UK evidence. International Journal of Managerial Finance, 2(4), 343-353.

17. Kumar, S., \& Sharma, A.K. (2011). Further evidence on relative and incremental information content of EVA and traditional performance measures from select Indian companies. Journal of Financial Reporting \& Accounting, 9(2), 104-118.

18. Kyriazis, D., \& Anastassis, C. (2007). The validity of the Economic Value Added approach: An empirical application. European Financial Management, 13(1), 71-100.

19. Lee, L., \& Kim, W. G. (2009). EVA, refined EVA, MVA, or traditional performance measures for the hospitality industry? International Journal for Hospitality Management, 28, 439-445.

20. Milunovich, S., \& Tsuei, A. (1996). EVA in the computer industry. Journal of Applied Corporate Finance, 9(1), 104-115.

21. O'Byrne, S. F. (1996). EVA and market value. Journal of Applied Corporate Finance, 9(1), 116-125. 
22. Sharma, A. K., \& Kumar, S. (2010). Economic Value Added (EVA) - Literature review and relevant issues. International Journal of Economics and Finance, 2(2), 200-220.

23. Stern, J. (1993). Value and people management. Corporate Finance, July, 35-37.

24. Stewart, G. B. (1991). The quest for value: The EVA ${ }^{T M}$ management guide. New York, NY: Harper Business.

25. Worthington, A. C., \& West, T. (2004). Australian evidence concerning the information content of Economic Value Added. Australian Journal of Management, 29(2), 201-223. 


\section{$\underline{\text { NOTES }}$}

